\title{
SELIGMAN CRYSTAL
}

The Council of the Glaciological Society have unanimously agreed to institute an award to be known as the Seligman Crystal. The Council felt that the science of glaciology and the Society itself had become sufficiently established to justify this.

It is not the intention that the Seligman Crystal shall be awarded annually, but that it shall be used to honour from time to time individuals of particular eminence in the field of glaciology.

The Seligman Crystal will take the form of a hexagonal prism of crystal glass mounted on a wooden base and will be inscribed: Seligman Crystal-Glaciological Society[NAME OF RECiPIENT]- [DATE]. Each Crystal will also bear a snow crystal design which will be different for each award.

The Council decided that it would be most appropriate for the first award to honour the founder of the Society on the occasion of his retirement from the Presidency. On 2 May I963 the first Seligman Crystal was accordingly presented to Gerald Seligman in recognition of his lifelong services to glaciology.

A photograph of the first Seligman Crystal will appear in the next issue of the Fournal of Glaciology. A full account of the proceedings and speeches at the Annual General Meeting will be given in the July issue of the Society's news bulletin, Ice.

V. E. Fuchs

Chairman of Council, The Glaciological Society 